\title{
PRODUCTION OF BARUZEIRO SEEDLING IN DIFFERENT PROTECTED ENVIRONMENTS AND SUBSTRATES
}

\section{EDILSON COSTA ${ }^{1}$, LETÍCIA C. DE OLIVEIRA ${ }^{2}$, TIAGO L. DO ESPÍRITO SANTO, PAULO A. M. LEAL ${ }^{4}$}

\begin{abstract}
The high seedlings quality is essential for deployment of homogeneous orchards. This study evaluated the baruzeiro (Dipteryx alata $\mathrm{Vog}$ ) seedlings formation on different substrates within protected environments. It was used substrates with $100 \%$ of cattle manure; $100 \%$ of cassava stems; $100 \%$ of vermiculite; $50 \%$ of cattle manure $+50 \%$ of cassava stems; $50 \%$ of cattle manure + $50 \%$ of vermiculite; $50 \%$ of cassava stems $+50 \%$ of vermiculite; and $+1 / 3$ of cattle manure $+1 / 3$ of cassava stems $+1 / 3$ of vermiculite. These substrates were tested in protected areas: greenhouse; black shade net of 50\% shading; and aluminized thermo-reflective screen of $50 \%$ shading. A completely randomized experimental design with five replicates of four plants was adopted. Initially, data were submitted to analysis of individual variance of the substrates, in each environment of cultivation, then performing the evaluation of the residual mean square and the analysis of these environments together for comparison. The best substrate for baruzeiro seedlings was pure vermiculite. The substrates with $100 \%$ of manure and the substrate with $33.33 \%$ of the mixed studied materials can be used for seedlings formation. The environment with screen can be indicated for the production of baruzeiro seedlings, since it gave vigor to the seedlings.
\end{abstract}

KEYWORDS: Dipteryx alata, cattle manure, cassava stems, vermiculite, protected cultivation.

\section{PRODUÇÃO DE MUDAS DE BARUZEIRO EM DIFERENTES AMBIENTES PROTEGIDOS E SUBSTRATOS}

RESUMO: A qualidade da muda é fundamental para implantação de pomares homogêneos. Desta forma, avaliou-se a formação de mudas de baruzeiro (Dipteryx alata Vog), em diferentes substratos, no interior de ambientes protegidos. Foram utilizados substratos com 100\% de esterco bovino; $100 \%$ de ramas de mandioca; $100 \%$ de vermiculita; $50 \%$ de esterco bovino $+50 \%$ de ramas de mandioca; $50 \%$ de esterco bovino $+50 \%$ de vermiculita; $50 \%$ de ramas de mandioca $+50 \%$ de vermiculita e $1 / 3$ de esterco bovino $+1 / 3$ de ramas de mandioca $+1 / 3$ de vermiculita. Estes substratos foram testados em ambientes protegidos: estufa agrícola; telado de tela preta com $50 \%$ de sombreamento e o telado de tela termorrefletora aluminizada com 50\% de sombreamento. Foi adotado o delineamento experimental inteiramente casualizado, com cinco repetições de quatro plantas cada. Inicialmente, os dados foram submetidos às análises de variâncias individuais dos substratos em cada ambiente de cultivo, realizando em seguida a avaliação dos quadrados médios dos resíduos e a análise conjunta dos ambientes. O melhor substrato para a formação das mudas do baruzeiro foi a vermiculita pura. O substrato com $100 \%$ de esterco e o substrato com 33,33\% dos materiais estudados podem ser indicados para a formação das mudas. Os telados podem ser indicados para produção de mudas de baruzeiro, pois conferiram vigor às mesmas.

PALAVRAS-CHAVE: Dipteryx alata, esterco bovino, ramas de mandioca, vermiculita, cultivo protegido.

\section{INTRODUCTION}

\footnotetext{
${ }^{1}$ Prof. Adjunto, Universidade Estadual de Mato Grosso do Sul, Unidade Universitária de Cassilândia - MS, mestrine@uems.br.

${ }^{2}$ Bolsista PIBIC/UEMS, Aquidauana - MS, leticia_agroaqui@hotmail.com.

${ }^{3}$ Bolsista PIBIC/CNPq, Aquidauana - MS, tiagropec@hotmail.com.

${ }^{4}$ Professor Titular, FEAGRI-UNICAMP, Campinas - SP, pamleal@ feagri.unicamp.br.

Recebido pelo Conselho Editorial em: 13-7-2011

Aprovado pelo Conselho Editorial em: 4-3-2012
} 
The baruzeiro (Dipteryx alata Vog.), a tree species irregularly distributed in the Cerrado landscape, has many uses, both the plant and the fruit (VERA \& SOUZA, 2009). Plants are used as timber in construction, shading in grasslands and recovery of degraded areas. From the fruit, it is consumed the pulp (flour and sweets) and the roasted seeds (almonds) (SANO et al., 2004; VERA \& SOUZA, 2009), in addition to oil extraction (SANO et al., 2004; VERA \& SOUZA, 2009).

Because of its hardiness and adaptability, it has great potential in productive systems (SANO et al., 2004; VERA \& SOUZA, 2009) and according to VENTUROLI et al. (2011) this native species from the cerrado has the potential to compose shrubland enrichment plantation systems. There is stagnation in the growth of seedlings during the winter (July to September), and reach $21.0 \mathrm{~cm}$ high in twelve months, with an average diameter of $6.9 \mathrm{~mm}$ (FERREIRA et al., 1998).

Seedling root characteristics may indicate heritability and genetic gains through selection matrices (OLIVEIRA et al., 2008), because distinct morphological groups can be obtained through the weight and dimensions of the fruit and seeds (SANO et al., 1999). According to CORREA et al. (2000), periods of the baruzeiro post-ripening seed, for two months, led high percentage of seedling emergence with uniform flock. The authors observed that there is high variability of this species according to their origin region.

The baruzeiro, also known by barueiro, cumarueiro, cumaruzeiro, cumbarueiro or cumbaruzeiro, is a promissory species for biodiesel production, thus demanding surveys throughout its production chain, starting with the formation of quality seedlings. For seedling formation, FONSECA et al. (1994) noted that the sowing must be accomplished between 1 and $3 \mathrm{~cm}$ deep.

The stage of seedling production phase is critical to achieving uniformity in the plants. At this stage, the type of substrate, type of protected environment, container volume, irrigation, fertilization and correct production operations management provide conditions for obtaining plants with high quality to ensure success in the development field. Fruitful seedlings obtained through studies of culture environments and substrates (COSTA et al., 2010; COSTA et al., 2011 a, b; SANTOS et al., 2011) show that the joint action of these factors provides better conditions for the initial development of the plant, giving vigor and robustness to seedlings to the deployment of orchards.

The State of Mato Grosso do Sul (MS), in Brazil, has great potential for commercial development of baruzeiro orchards, because apart from presenting native matrices, it has large tracts of available areas, demanding surveys throughout the production chain, starting with the formation of high-quality seedlings. Given the above, this study was conducted to evaluate the production of baruzeiro seedlings using different substrates and cultivation environments in the region of Aquidauana, MS.

\section{MATERIAL AND METHODS}

Experiments with the formation of baruzeiro seedlings (Dipteryx alata Vog) on different substrates and cultivation environments were conducted from September $28^{\text {th }}$ to December $12^{\text {th }}$, 2010 (75 days) at the Universidade Estadual de Mato Grosso do Sul, Unidade Universitária de Aquidauana, with altitude of $174 \mathrm{~m}$, longitude $55^{\circ} 40^{\prime} \mathrm{W}$ and latitude $20^{\circ} 27^{\prime} \mathrm{S}$. The climate, according to Köeppen, is Aw, defined as humid tropical climate, with average annual temperature between 27 and $29^{\circ} \mathrm{C}$.

As a container for the seedling formation it was used black perforated polyethylene bags of $15.0 \times 25.0 \mathrm{~cm}(1.8 \mathrm{~L})$, filled with the following substrates: $(100 \% \mathrm{CM}) 100 \%$ of cattle manure; ( $100 \%$ CS $) 100 \%$ of cassava stems; $(100 \%$ V) $100 \%$ of vermiculite, $(1 / 2 \mathrm{CM}+1 / 2 \mathrm{CS}) 50 \%$ of cattle manure $+50 \%$ of cassava stems; $(1 / 2 \mathrm{CM}+1 / 2 \mathrm{~V}) 50 \%$ of cattle manure $+50 \%$ of vermiculite, $(1 / 2 \mathrm{CS}+1 / 2 \mathrm{~V}) 50 \%$ of cassava stems $+50 \%$ of vermiculite and $(1 / 3 \mathrm{CM}+1 / 3 \mathrm{CS}+1 / 3 \mathrm{~V}) 1 / 3$ of cattle manure $+1 / 3$ of cassava stems $+1 / 3$ of vermiculite (Table 1 ). It was used medium-texture vermiculite. It was used cassava stems and cattle manure, agricultural residues abundant in the region of Aquidauana, MS. 
TABLE 1. Chemical analysis of the substrate organic materials used in the baruzeiro experiment. Aquidauana - MS, 2010.

\begin{tabular}{|c|c|c|c|c|c|c|c|c|}
\hline & \multicolumn{8}{|c|}{-------------------------------------------- g kg $^{-1}$} \\
\hline & $\mathrm{N}$ & $\mathrm{P}$ & K & $\mathrm{Ca}$ & $\mathrm{Mg}$ & $\mathrm{S}$ & $\mathrm{C}$ & $\mathrm{OM}$ \\
\hline $\mathrm{CM}$ & 9.30 & 1.82 & 1.00 & 4.95 & 0.90 & 1.07 & 112.00 & 192.00 \\
\hline \multirow[t]{3}{*}{ CS } & 26.70 & 6.62 & 29.00 & 27.45 & 7.70 & 3.25 & 483.00 & 830.00 \\
\hline & - & - & - & & --- & $\mathrm{mg} \mathrm{kg}^{-1}$ & & -- \\
\hline & $\mathrm{pH}$ & $\mathrm{H}$ & $\mathrm{C} / \mathrm{N}$ & $\mathrm{Cu}$ & $\mathrm{Zn}$ & $\mathrm{Fe}$ & Mn & B \\
\hline $\mathrm{CM}$ & 7.10 & 14.12 & 12.04 & 14.00 & 103.00 & 6000.00 & 239.50 & 12.19 \\
\hline $\mathrm{CS}$ & 8.80 & 65.04 & 18.09 & 16.50 & 170.00 & 910.00 & 223.00 & 28.75 \\
\hline
\end{tabular}

* Solanalise, Soil Analysis Laboratory, Dourados, MS. OM - organic matter; H - humidity in \% at $65{ }^{\circ} \mathrm{C}$; CM - cattle manure; CS cassava stems.

Treatments consisted of substrates tested in a galvanized steel structure arc agricultural greenhouse $(8.00 \mathrm{~m} \times 18.00 \mathrm{~m} \times 4.00 \mathrm{~m})$, with coping zenithal opening, covered with low-density polyethylene film (LDPE) of $150 \mu \mathrm{m}$, a light diffuser with $50 \%$ thermal reflector screen under the film and lateral and frontal locks with monofilament mesh, net for 50\% shade; galvanized steel structure agricultural nursery $(8.00 \mathrm{~m} \times 18.00 \mathrm{~m} \times 3.50 \mathrm{~m})$, black monofilament mesh greenhouse with $50 \%$ shading, closed at 45 degrees, and galvanized steel structure agricultural nursery $(8.00 \mathrm{~m}$ x $18.00 \mathrm{~m} \times 3.50 \mathrm{~m}$ ), thermal reflector screen with $50 \%$ shading, closed at 45 degrees. The environments were differentiated by the type of roofing and lateral material: the greenhouse covered with aluminized thermal reflector screen under the film and black mesh on the side; monofilament mesh roof and sides of black mesh with thermal reflector roofing and sides with aluminized screen.

For the evaluation of substrates inside the greenhouses was adopted a completely randomized design with four replications, each replication with 5 plants. The data were submitted to analysis of variance of individual substrates (for each culture environment), and then it was performed the evaluation of residual mean squares (BANZATTO \& KRONKA, 2006) and joint analysis of environments. It was used the statistical program Sisvar 5.3 (FERREIRA, 2010), and the averages were compared by F-test at $5 \%$ probability.

The collection of seed was performed in plants of the region, where it was collected fruit that have spontaneously broken off. Then, it was performed the withdrawal of almonds in the interior of the fruit with the help of manual vise. The seeds were selected with phytomass, ranging from 0.7 to $0.9 \mathrm{~g}$.

The sowing between 1 and $3 \mathrm{~cm}$ deep (FONSECA et al., 1994) occurred on September $28^{\text {th }}$, 2010, with two seeds per container, conducting thinning when they were with two definitive leaves. The emergency occurred on October $11^{\text {th }}$, on the thirteenth day after sowing (DAS). From October $11^{\text {th }}$ to $18^{\text {th }}$, the seedling emergence data were calculated, these being, emergency velocity index (EVI), percentage (PE), average time (AT) and average speed (AS). The counting procedure was as follows: From the moment that one of the treatments had stabilized, i.e., the values of the counting emerged plants began to repeat the last three samples, it was ceased.

It was also measured the plant height (PH) and leaf number (LN) at 30; 45; 60 and 75 DAS. At 75 , in addition to height and number of leaves, it was measured the stem diameter (SD), the phytomass dry matter (PMDM) and root system (RDM). The drying of phytomass was carried out in an oven with forced air at $65{ }^{\circ} \mathrm{C}$ for 72 hours. PMDM and RDM were added to obtain the total phytomass dry matter (TDM). It was determined the ratio between aerial and root phytomass dry matter (DMR), the ratio between height and diameter (HDR), the ratio between height and aerial dry phytomass (HMR) and Dickson quality index (DQI): 


$$
\mathrm{DQI}=\frac{\mathrm{TDM}(\mathrm{g})}{\frac{\mathrm{HS}(\mathrm{cm})}{\mathrm{SD}(\mathrm{mm})}+\frac{\mathrm{DMPM}(\mathrm{g})}{\operatorname{RDM}(\mathrm{g})}}
$$

Daily it was recorded the temperatures of the dry bulb $\left({ }^{\circ} \mathrm{C}\right)$ and wet bulb $\left({ }^{\circ} \mathrm{C}\right)$ at 09 a.m., 12 p.m. and 3 p.m. in every culture environment, throughout the period of the experimentation. It was later determined the relative humidity with the software Psychrometric Function Demo (Table 2). For the collections of temperatures, it was used analog thermo-hygrometer, dry and wet bulbs, at the center of the bench cultivation $1.0 \mathrm{~m}$ away from the ground.

TABLE 2. Temperature $\left({ }^{\circ} \mathrm{C}\right)$ and average relative humidity $(\%)$ at 9 a.m., 12 p.m. and 3 p.m. for each culture and external environment. Aquidauana - MS, 2010.

\begin{tabular}{|c|c|c|c|c|c|c|c|c|c|}
\hline & DBT & WBT & DBT & WBT & DBT & WBT & & $\mathrm{RH}$ & \\
\hline & \multicolumn{2}{|c|}{9 a.m. } & $12 \mathrm{p}$ & p.m. & $3 p$ & m. & 9 a.m. & 12 p.m. & 3 p.m. \\
\hline Greenhouse & 27.79 & 23.19 & 31.54 & 24.82 & 32.00 & 25.23 & 63.09 & 54.57 & 55.30 \\
\hline Black mesh & 27.95 & 23.90 & 31.42 & 25.30 & 32.16 & 25.97 & 70.64 & 58.78 & 60.86 \\
\hline Aluminized & 27.87 & 24.18 & 32.08 & 25.67 & 32.47 & 26.35 & 70.64 & 57.94 & 59.88 \\
\hline External & 27.37 & 23.95 & 31.43 & 25.58 & 32.10 & 25.85 & 71.03 & 60.05 & 59.37 \\
\hline
\end{tabular}

* DBT - dry bulb temperature $\left({ }^{\circ} \mathrm{C}\right)$; WBT - wet bulb temperature $\left({ }^{\circ} \mathrm{C}\right)$; RH - relative humidity $(\%)$.

The cattle manure was composted for 30 days, was wet and turned over to lower its temperature and change its color. The branches were crushed in a sieve-hammer mill 12 and composted for 30 days. Irrigation was manual with a watering can, performed twice a day - morning and evening - when necessary, until saturation of the substrate, observed by the beginning of the water flow. The substrates were fertilized with $2.5 \mathrm{~kg}$ of simple superphosphate $\left(\mathrm{P}_{2} \mathrm{O}_{5}\right), 0.3 \mathrm{~kg}$ of potassium chloride $(\mathrm{KCl}), 1.5 \mathrm{~kg}$ of dolomitic limestone filler (PRNT of $100 \%$ purity) and $50 \mathrm{~g}$ of $\mathrm{N}(108.33 \mathrm{~g}$ of urea, $46 \%$ of $\mathrm{N})$ per cubic meter.

TABLE 3. Percentage of crushed cassava cuttings, retained on each sieve. Aquidauana - MS, 2010.

\begin{tabular}{ccc}
\hline Seive $\left(\mathrm{ABNT}^{\mathbf{0}}\right)$ & Holes $(\mathrm{mm})$ & \% of Material \\
\hline 5 & 4.0 & 3.03 \\
10 & 2.0 & 50.76 \\
16 & 1.2 & 15.55 \\
30 & 0.6 & 19.91 \\
50 & 0.3 & 7.50 \\
100 & 0.15 & 2.27 \\
Bottom & 0.0 & 0.95 \\
\hline
\end{tabular}

\section{RESULTS AND DISCUSSION}

For all evaluated parameters, the ratio of residual mean squares (RRMS) analysis of individual variance of the experiments did not exceed the ratio of $7: 1$, thus enabling the realization of joint analysis of the experiments (BANZATTO \& KRONKA, 2006). There was an interaction between substrates and culture environments for the mean time of emergence (AT), mean speed of emergence (AS), number of leaves at 30 DAS and root system dry phytomass (RDM) of baruzeiro seedlings. There was no interaction between the two factors studied for the other variables.

In the agricultural greenhouse, the longer seedling mean time of emergence was observed in the substrate $1 / 2 \mathrm{CS}+1 / 2 \mathrm{~V}$, and in the screens, (black and aluminized) this variable and the mean speed of emergence did not differ between the substrates studied. In agricultural greenhouse, the seedlings from the substrate $100 \% \mathrm{CM}$ presented higher mean speed of emergence than the $100 \% \mathrm{~V}$ and $1 / 2 \mathrm{CS}+1 / 2 \mathrm{~V}$ (Table 4$)$. 
Evaluating the environment variables for each substrate in AT and AS, it can be verified for the substrates $100 \% \mathrm{CM}, 100 \% \mathrm{CS}, 1 / 2 \mathrm{CM}+1 / 2 \mathrm{CS}, 1 / 2 \mathrm{CM}+1 / 2 \mathrm{~V}$ that the seedlings were not different among culture environments, as well as the AT of the substrate $1 / 3 \mathrm{CM}+1 / 3 \mathrm{CS}+1 / 3 \mathrm{~V}$. The cultivation environments showed similar temperature and relative humidity in the time of collection (Table 2), as observed by COSTA et al. (2010 b) in papaya seedlings and COSTA et al. (2011 c) in the formation of yellow passion fruit seedlings in comparing these environments, which probably did not affect seedling emergence in the aforementioned substrates.

For other substrates $(100 \% \mathrm{~V}$ and $1 / 2 \mathrm{CS}+1 / 2 \mathrm{~V})$, the seedlings in the agricultural greenhouse had a higher mean time and lower mean speed of emergence than the aluminized thermal reflector screen (Table 4), verifying that the thermal reflector screen showed better conditions for seedling emergence in these substrates, because GUISELINI \& SENTELHAS (2004) point out that the average temperature of the air inside greenhouses, there is no difference between greenhouses with screens and the ones without screens, however the use of thermal reflector screen improves the distribution in terms of diffuse radiation to the plants, because these screens promote lower transmittance and absorption and higher reflectance.

TABLE 4. Interactions between environments and substrates for average time of emergency (AT), average speed of emergency (AS), number of leaves at 30 DAS (LN1) and root system dry phytomass of baruzeiro seedlings (RDM). Aquidauana - MS, 2010.

\begin{tabular}{lllllll}
\hline \multicolumn{1}{c}{$* *$} & \multicolumn{5}{c}{$\mathrm{AT}$} \\
\hline $100 \% \mathrm{CM}$ & Greenhouse & Black mesh & Aluminized Screen & Greenhouse & Black mesh Aluminized screen \\
$100 \% \mathrm{CS}$ & $17.74 \mathrm{Ba} *$ & $18.29 \mathrm{Aa}$ & $18.30 \mathrm{Aa}$ & $0.0564 \mathrm{Aa}$ & $0.0547 \mathrm{Aa}$ & $0.0547 \mathrm{ABa}$ \\
$100 \% \mathrm{~V}$ & $18.45 \mathrm{Ba}$ & $18.37 \mathrm{Aa}$ & $18.20 \mathrm{Aa}$ & $0.0542 \mathrm{ABCa}$ & $0.0544 \mathrm{Aa}$ & $0.0550 \mathrm{ABa}$ \\
$1 / 2 \mathrm{CM}+1 / 2 \mathrm{CS}$ & $18.44 \mathrm{Ba}$ & $18.18 \mathrm{Aab}$ & $17.64 \mathrm{Ab}$ & $0.0542 \mathrm{BCb}$ & $0.0550 \mathrm{Aab}$ & $0.0567 \mathrm{Aa}$ \\
$1 / 2 \mathrm{CM}+1 / 2 \mathrm{~V}$ & $17.91 \mathrm{Ba}$ & $18.36 \mathrm{Aa}$ & $18.10 \mathrm{Aa}$ & $0.0559 \mathrm{ABa}$ & $0.0545 \mathrm{Aa}$ & $0.0552 \mathrm{ABa}$ \\
$1 / 2 \mathrm{CS}+1 / 2 \mathrm{~V}$ & $18.17 \mathrm{Ba}$ & $17.97 \mathrm{Aa}$ & $18.34 \mathrm{Aa}$ & $0.0551 \mathrm{ABa}$ & $0.0557 \mathrm{Aa}$ & $0.0546 \mathrm{Ba}$ \\
$1 / 3 \mathrm{CM}+1 / 3 \mathrm{CS}+1 / 3 \mathrm{~V}$ & $19.19 \mathrm{Aa}$ & $18.49 \mathrm{Ab}$ & $18.19 \mathrm{Ab}$ & $0.0522 \mathrm{Cb}$ & $0.0541 \mathrm{Aa}$ & $0.0550 \mathrm{ABa}$ \\
& $18.17 \mathrm{Ba}$ & $17.98 \mathrm{Aa}$ & $17.62 \mathrm{Aa}$ & $0.0551 \mathrm{ABb}$ & $0.0556 \mathrm{Aab}$ & $0.0567 \mathrm{Aa}$ \\
$100 \% \mathrm{CM}$ & & $\mathrm{LN} \mathrm{at} 30 \mathrm{DAS}$ & & $\mathrm{RDM}$ & & \\
$100 \% \mathrm{CS}$ & $2.77 \mathrm{Aa}$ & $2.27 \mathrm{ABb}$ & $2.38 \mathrm{BCab}$ & $0.56 \mathrm{ABa}$ & $0.47 \mathrm{Ba}$ & $0.57 \mathrm{BCa}$ \\
$100 \% \mathrm{~V}$ & $2.20 \mathrm{Ba}$ & $2.57 \mathrm{ABa}$ & $2.15 \mathrm{Ca}$ & $0.48 \mathrm{Ba}$ & $0.54 \mathrm{Ba}$ & $0.55 \mathrm{BCa}$ \\
$1 / 2 \mathrm{CM}+1 / 2 \mathrm{CS}$ & $2.50 \mathrm{ABa}$ & $2.38 \mathrm{ABa}$ & $2.80 \mathrm{ABa}$ & $0.78 \mathrm{Ab}$ & $1.12 \mathrm{Aa}$ & $1.25 \mathrm{Aa}$ \\
$1 / 2 \mathrm{CM}+1 / 2 \mathrm{~V}$ & $2.70 \mathrm{ABab}$ & $2.73 \mathrm{Aa}$ & $2.27 \mathrm{BCb}$ & $0.46 \mathrm{Ba}$ & $0.51 \mathrm{Ba}$ & $0.47 \mathrm{Ca}$ \\
$1 / 2 \mathrm{CS}+1 / 2 \mathrm{~V}$ & $2.58 \mathrm{ABa}$ & $2.47 \mathrm{ABa}$ & $2.42 \mathrm{ABCa}$ & $0.48 \mathrm{Ba}$ & $0.47 \mathrm{Ba}$ & $0.61 \mathrm{BCa}$ \\
$1 / 3 \mathrm{CM}+1 / 3 \mathrm{CS}+1 / 3 \mathrm{~V}$ & $2.42 \mathrm{ABa}$ & $2.10 \mathrm{Ba}$ & $2.10 \mathrm{Ca}$ & $0.40 \mathrm{Bb}$ & $0.52 \mathrm{Bab}$ & $0.63 \mathrm{BCa}$ \\
\hline
\end{tabular}

*Equal capital letters in the columns and lower case letters in the rows, for each parameter; do not differ by the Tukey's Test at a probability of 5\%.** CM - cattle manure; CS - cassava stems, V - vermiculite.

For the first count of the number of leaves (30 DAS), which was no interaction with different environments and type of substrates, it was observed in the agricultural greenhouse that plants of the substrate $100 \%$ CM presented more leaves than those of the $100 \%$ CS ( Table 4). In the black mesh, seedlings of substrate $1 / 2 \mathrm{CM}+1 / 2 \mathrm{CS}$ had more leaves than those of the substrate $1 / 2 \mathrm{CS}+1 / 2 \mathrm{~V}$. For aluminized screen greenhouse, it is verified that the seedlings grown in trays containing the mixture of the three substrates exhibited higher leaf number than those grown on substrates containing $100 \%$ or $50 \%$ of stems (Table 4). For SILVA et al. (2010) the best results for the number of leaves per plant seedlings of passion fruit were obtained on substrates containing manure, as found in the present study.

Comparing the environments for each substrate is observed that the number of leaves of the seedlings cultivated in the substrates $100 \% \mathrm{CS}, 100 \% \mathrm{~V}, 1 / 2 \mathrm{CM}+1 / 2 \mathrm{~V}$, and $1 / 2 \mathrm{CS}+1 / 2 \mathrm{~V}$ did not present differences between the cultivation environments. For substrate $100 \% \mathrm{CM}$, the plants had more leaves in the greenhouse than in the black mesh environment. Regarding the mixture of the three materials, it was verified larger number of leaves of the seedlings in the aluminized screen than in the black mesh environment. To CARVALHO FILHO et al. (2003), in the production of 
jatoba seedlings (Hymenaea courbaril L.), the lowest number of leaves was observed in plants of the black mesh environment compared to full sun. In the present study, for this collection, the smallest quantities of leaves of plants grown in substrates aforementioned also were found in the black mesh environment (Table 4).

For the variable root system dry phytomass (RDM), it was found in the three environments that seedlings produced in $100 \% \mathrm{~V}$ substrate showed better root development, which did not differ in the seedlings of substrate $100 \% \mathrm{CM}$. Vermiculite has a great capacity to absorb water and improved conditions for root development, in accordance to COSTA et al. (2010 c) in the evaluation of yellow passion fruit seedlings phytomasses, and COSTA et al. (2009) in papaya seedlings, as well as COSTA et al. (2011 b) in the formation of jatobazeiro-do-cerrado seedlings environments.

The seedlings of $100 \% \mathrm{~V}$ substrates showed better root development in both environments, compared to the agricultural greenhouse, as verified by COSTA et al. (2010 c) in seedlings of yellow passion fruit and COSTA et al. (2009) in papaya seedlings. For the seedlings of substrates $1 / 2$ $\mathrm{CS}+1 / 2 \mathrm{~V}$, and $1 / 3 \mathrm{CM}+1 / 3 \mathrm{CS}+1 / 3 \mathrm{~V}$, the aluminized thermal reflector produced better results of higher mean speed of emergency that the greenhouse (Table 4). The aluminized thermal reflector environment, besides providing greater diffuse radiation (GUISELINI \& SENTELHAS, 2004) has a higher nighttime heat loss by re-radiation, depending on the fabric to be aluminized, which might have improved the temperature of the substrates and promoted satisfactory root development of gerbera (Gerbera jamesonii). In papaya seedlings, COSTA et al. (2009) found higher dry phytomasses in the aerial part in thermal reflector environment.

During evaluation of substrates for variables which showed no interaction (Table 5) it was observed that the plants of substrate $100 \% \mathrm{~V}$ showed improved development. Seedlings of substrates $100 \% \mathrm{CM}$ and $1 / 3 \mathrm{CM}+1 / 3 \mathrm{CS}+1 / 3 \mathrm{~V}$ also showed growth and development that characterized vigorous seedlings (Table 5).

Both vermiculite, which had already showed better results for other fruit (COSTA et al., 2009; COSTA et al., $2010 \mathrm{c}$ ), and the substrates containing 100\% cattle manure or 33.33\%, promoted best physical structure to the substrates (aeration, moisture retention and porosity) and facilitated nutrient absorption by baruzeiro seedlings. DIAS et al. (2009) found that the use of manure above $10 \%$ in substrate reduced root development and leaf expansion of mangaba seedlings cultivated in a greenhouse, different from what was observed in the present study. Probably there was insufficient composted manure used to the mangaba used for seedlings, since it is not reported and commented. However SILVA et al. (2009) reported that the use of 10 and $20 \%$ cattle manure promoted healthy mangaba seedlings.

The substrates with pure or mixtures of $50 \%$ of crushed stems presented lower aerial dry and total phytomass seedlings (Table 5). The cassava foliage, even with equal composting time of cattle manure had higher $\mathrm{C} / \mathrm{N}$ ratio (Table 1), promoting lower availability of nutrients in substrates that contained it, due to lower organic matter degradation, restricting the development of seedlings.

COSTA et al. (2011 d) found that the mixture of crude vermiculite with mashed cassava (fertilized), ranging from 40 to $60 \%$, led the best eggplant seedlings at 56 DAS, noting that the material used was not composted, only dried in the sun for one week and had C/N ratio of 31.12. The same authors report that they could burn the branches or compose it. In the present study, the composting of 30 days decreased the $\mathrm{C} / \mathrm{N}$ ratio (18.09), but was not sufficient to provide highquality seedlings of baruzeiro. 
TABLE 5. Emergence speed index (ESI), emergency percentage (EP), plants height at 30; 45; 60 and 75 DAS (PH1, PH2, PH3 and PH4, respectively), leaves number at 45; 60 and 75 DAS (LN2, LN3 and LN4, respectively), stem diameter (SD), aerial dry phytomass (PMDM), total dry phytomass (TDM), ratio between aerial and root dry phytomass (DMR), ratio between plant height and aerial dry phytomass (HMR), ratio between height and diameter (HDR) and Dickson quality index (DQI) for baruzeiro seedlings in cultivation substrates. Aquidauana - MS, 2010.

\begin{tabular}{lllllllll}
\hline \multicolumn{1}{c}{$* *$} & \multicolumn{1}{c}{$\mathrm{ESI}$} & $\mathrm{EP}$ & $\mathrm{PH} 1$ & $\mathrm{PH} 2$ & $\mathrm{PH} 3$ & $\mathrm{PH} 4$ & $\mathrm{LN} 2$ & $\mathrm{LN} 3$ \\
$100 \% \mathrm{CM}$ & $0.94 \mathrm{BC} *$ & $50.0 \mathrm{~B}$ & $8.3 \mathrm{~B}$ & $11.7 \mathrm{AB}$ & $13.3 \mathrm{~A}$ & $15.4 \mathrm{~A}$ & $3.8 \mathrm{AB}$ & $5.2 \mathrm{~A}$ \\
$100 \% \mathrm{CS}$ & $0.92 \mathrm{BC}$ & $53.3 \mathrm{~B}$ & $8.1 \mathrm{~B}$ & $10.5 \mathrm{~B}$ & $11.6 \mathrm{~B}$ & $12.2 \mathrm{~B}$ & $3.2 \mathrm{C}$ & $4.0 \mathrm{C}$ \\
$100 \% \mathrm{~V}$ & $1.57 \mathrm{~A}$ & $77.5 \mathrm{~A}$ & $10.3 \mathrm{~A}$ & $13.7 \mathrm{~A}$ & $14.4 \mathrm{~A}$ & $15.2 \mathrm{~A}$ & $4.0 \mathrm{~A}$ & $4.8 \mathrm{AB}$ \\
$1 / 2 \mathrm{CM}+1 / 2 \mathrm{CS}$ & $1.12 \mathrm{ABC}$ & $57.5 \mathrm{AB}$ & $9.1 \mathrm{AB}$ & $12.1 \mathrm{AB}$ & $13.4 \mathrm{AB}$ & $13.6 \mathrm{AB}$ & $3.7 \mathrm{ABC}$ & $4.4 \mathrm{BC}$ \\
$1 / 2 \mathrm{CM}+1 / 2 \mathrm{~V}$ & $1.07 \mathrm{CB}$ & $56.7 \mathrm{AB}$ & $8.9 \mathrm{AB}$ & $11.4 \mathrm{~B}$ & $12.2 \mathrm{~B}$ & $12.6 \mathrm{~B}$ & $3.5 \mathrm{ABC}$ & $4.1 \mathrm{C}$ \\
$1 / 2 \mathrm{CS}+1 / 2 \mathrm{~V}$ & $0.87 \mathrm{C}$ & $52.5 \mathrm{~B}$ & $7.7 \mathrm{~B}$ & $10.6 \mathrm{~B}$ & $11.3 \mathrm{~B}$ & $11.8 \mathrm{~B}$ & $3.3 \mathrm{BC}$ & $4.1 \mathrm{C}$ \\
$1 / 3 \mathrm{CM}+1 / 3 \mathrm{CS}+1 / 3 \mathrm{~V}$ & $1.39 \mathrm{AB}$ & $65.8 \mathrm{AB}$ & $9.0 \mathrm{AB}$ & $12.3 \mathrm{AB}$ & $13.4 \mathrm{~A}$ & $15.0 \mathrm{~A}$ & $3.9 \mathrm{~A}$ & $5.1 \mathrm{~A}$ \\
\hline & $\mathrm{LN} 4$ & $\mathrm{SD}$ & $\mathrm{PMDM}$ & $\mathrm{TDM}$ & $\mathrm{DMR}$ & $\mathrm{HMR}$ & $\mathrm{HDR}$ & $\mathrm{DQI}$ \\
$100 \% \mathrm{CM}$ & $6.4 \mathrm{~A}$ & $5.1 \mathrm{~A}$ & $2.0 \mathrm{AB}$ & $2.5 \mathrm{~B}$ & $3.7 \mathrm{~A}$ & $8.2 \mathrm{C}$ & $3.0 \mathrm{~A}$ & $0.37 \mathrm{~B}$ \\
$100 \% \mathrm{CS}$ & $4.8 \mathrm{C}$ & $4.7 \mathrm{AB}$ & $1.0 \mathrm{C}$ & $1.6 \mathrm{C}$ & $2.0 \mathrm{D}$ & $11.9 \mathrm{~A}$ & $2.7 \mathrm{~A}$ & $0.34 \mathrm{~B}$ \\
$100 \% \mathrm{~V}$ & $5.7 \mathrm{AB}$ & $5.1 \mathrm{AB}$ & $2.2 \mathrm{~A}$ & $3.2 \mathrm{~A}$ & $2.2 \mathrm{D}$ & $7.1 \mathrm{C}$ & $3.0 \mathrm{~A}$ & $0.63 \mathrm{~B}$ \\
$1 / 2 \mathrm{CM}+1 / 2 \mathrm{CS}$ & $5.0 \mathrm{BC}$ & $5.0 \mathrm{AB}$ & $1.3 \mathrm{C}$ & $1.7 \mathrm{C}$ & $2.7 \mathrm{BC}$ & $11.1 \mathrm{AB}$ & $2.7 \mathrm{~A}$ & $0.33 \mathrm{~B}$ \\
$1 / 2 \mathrm{CM}+1 / 2 \mathrm{~V}$ & $5.0 \mathrm{BC}$ & $4.8 \mathrm{AB}$ & $1.2 \mathrm{C}$ & $1.7 \mathrm{C}$ & $2.3 \mathrm{CD}$ & $11.4 \mathrm{AB}$ & $2.7 \mathrm{~A}$ & $0.34 \mathrm{~B}$ \\
$1 / 2 \mathrm{CS}+1 / 2 \mathrm{~V}$ & $4.9 \mathrm{C}$ & $4.5 \mathrm{~B}$ & $1.0 \mathrm{C}$ & $1.5 \mathrm{C}$ & $2.0 \mathrm{D}$ & $12.6 \mathrm{~A}$ & $2.7 \mathrm{~A}$ & $0.33 \mathrm{~B}$ \\
$1 / 3 \mathrm{CM}+1 / 3 \mathrm{CS}+1 / 3 \mathrm{~V}$ & $6.2 \mathrm{~A}$ & $5.1 \mathrm{AB}$ & $1.6 \mathrm{~B}$ & $2.2 \mathrm{~B}$ & $2.9 \mathrm{~B}$ & $9.4 \mathrm{BC}$ & $3.0 \mathrm{~A}$ & $0.39 \mathrm{~A}$ \\
\hline
\end{tabular}

*Equal capital letters in the columns for each parameter do not differ by the Tukey's Test at a probability of 5\%.** CM - cattle manure; CS - cassava stems, V - vermiculite.

In the present study it was observed that the use 33.3 or $100 \%$ of cattle manure promote seedling quality different from what was found byPAIVA SOBRINHO et al. (2010), that evaluated the formation of seedlings in soil substrates; soil + hardened cattle manure (1:1); soil + carbonized rice hull (1:1), and soil + hardened cattle manure + carbonized rice hulls (1:1:1) under mesh of 50\% shading and found the best baruzeiro seedlings in pure soil, showing higher root and aerial dry phytomasses.

In evaluating cultivation environments for variables that showed no interaction (Table 6), it was observed that the seedlings from the agricultural nursery with thermo-reflective screen had higher emergence speed index (ESI) and a lower ratio between the dry phytomasses from the aerial and root parts than in other environments, as well as higher Dickson quality index that the greenhouse. For emergency percentage (EP) and seedling height, the seedlings did not differ from that environment and the greenhouse were higher than those of the monofilament environment.

TABLE 6. Emergence speed index (ESI), emergency percentage (EP), plants height at 30, 45, 60 and 75 DAS (PH1, PH2, PH3 and PH4, respectively), leaves number at 45, 60 and 75 DAS (LN2, LN3 and LN4, respectively), stem diameter (SD), aerial dry phytomass (PMDM), total dry phytomass (TDM), relation between aerial and root dry phytomass (DMR), relation between plant height and aerial dry phytomass (HMR), relation between height and diameter (HDR) and Dickson quality index (IQD) for baruzeiro seedlings in cultivation substrates. Aquidauana - MS, 2010.

\begin{tabular}{lcccccccc}
\hline & ESI & PE & PH1 & PH2 & PH3 & PH4 & LN2 & LN3 \\
\hline Greenhouse & $1.03 \mathrm{~B} *$ & $57.5 \mathrm{AB}$ & $9.3 \mathrm{~A}$ & $11.7 \mathrm{~A}$ & $12.5 \mathrm{~A}$ & $13.4 \mathrm{~A}$ & $3.6 \mathrm{~A}$ & $4.6 \mathrm{~A}$ \\
Black mesh & $0.98 \mathrm{~B}$ & $53.6 \mathrm{~B}$ & $8.4 \mathrm{~B}$ & $11.7 \mathrm{~A}$ & $13.1 \mathrm{~A}$ & $13.6 \mathrm{~A}$ & $3.6 \mathrm{~A}$ & $4.5 \mathrm{~A}$ \\
Aluminuzed screen & $1.37 \mathrm{~A}$ & $66.1 \mathrm{~A}$ & $8.6 \mathrm{AB}$ & $11.9 \mathrm{~A}$ & $12.8 \mathrm{~A}$ & $14.1 \mathrm{~A}$ & $3.7 \mathrm{~A}$ & $4.6 \mathrm{~A}$ \\
\hline & LN4 & SD & PMDM & TDM & DMR & HMR & HDR & IQD \\
Greenhouse & $5.4 \mathrm{~A}$ & $4.9 \mathrm{~A}$ & $1.48 \mathrm{~A}$ & $2.01 \mathrm{~A}$ & $2.87 \mathrm{~A}$ & $9.8 \mathrm{~A}$ & $2.74 \mathrm{~A}$ & $0.36 \mathrm{~B}$ \\
Black mesh & $5.3 \mathrm{~A}$ & $5.0 \mathrm{~A}$ & $1.38 \mathrm{~A}$ & $1.98 \mathrm{~A}$ & $2.44 \mathrm{~B}$ & $10.6 \mathrm{~A}$ & $2.75 \mathrm{~A}$ & $0.39 \mathrm{AB}$ \\
Aluminuzed screen & $5.6 \mathrm{~A}$ & $4.9 \mathrm{~A}$ & $1.51 \mathrm{~A}$ & $2.19 \mathrm{~A}$ & $2.27 \mathrm{~B}$ & $10.3 \mathrm{~A}$ & $2.93 \mathrm{~A}$ & $0.435 \mathrm{~A}$ \\
\hline
\end{tabular}

\footnotetext{
*Equal capital letters in the columns for each parameter do not differ by the Tukey's Test at a probability of 5\%.
} 


\section{CONCLUSIONS}

The best substrate for the baruzeiro seedling is pure vermiculite.

The substrate with $100 \%$ manure and the one with $33.33 \%$ of the studied materials can be suitable for the formation of the seedlings.

The screened environments can be indicated for baruzeiro seedling production because it gave vigor to the plants.

The substrates containing stems of pure cassava or the proportion of $50 \%$, composted for 30 days, is not indicated for baruzeiro seedlings, because it was not suitable, even using chemical fertilizer.

\section{ACKNOWLEDMENTS}

To the Pro-Rectory and Post-Graduation (PROPP) and the Unidade Universitária de Aquidauana da Universidade Estadual de Mato Grosso do Sul.

\section{REFERENCES}

BANZATTO, D. A.; KRONKA, S. N. Experimentação agrícola. 4.ed. Jaboticabal: FUNEP/ UNESP, 2006. 237 p.

CARVALHO FILHO, J. L.S.; ARRIGONI-BLANK, M.F.; BLANK, A.F.; ALVES RANGEL, M.S. Produção de mudas de jatobá (Hymenaea courbaril L.) em diferentes ambientes, recipientes e composições de substratos. Cerne, Lavras, v.9, n.1, p.109-118, 2003.

CORRÊA, G.C.; ROCHA, M.R.; NAVES, R.V. Germinação de sementes e emergência de plântulas de baru (Dipteryx alata Vog.) nos Cerrados do Estado de Goiás. Pesquisa Agropecuária Tropical, Goiânia, v.30, n.2, p.17-23, 2000.

COSTA, E. ; SANTOS, L.C.R.; VIEIRA, L C.R. Produção de mudas de mamoeiro utilizando diferentes substratos, ambientes de cultivo e recipientes. Engenharia Agrícola, Jaboticabal, v.29, n.4, p.528-537, 2009.

COSTA, E.; LEAL, P.A.M.; SASSAQUI, A.R.; GOMES, V.A.G. Doses de composto orgânico comercial na composição de substratos para a produção de mudas de maracujazeiro em diferentes tipos de cultivo protegido. Engenharia Agrícola, Jaboticabal, v.30, n.5, p.776-787, 2010 a.

COSTA, E.; GOMES, V.A.; LEAL, P.A.M.; ABOT, A.R.; FERNANDES, C.D. Formação de mudas de mamão em ambientes de cultivo protegido em diferentes substratos. Revista Ceres, Lavras, v.57, n.5, p.679-685, 2010 b.

COSTA, E.; LEAL, P.A.M.; SANTOS, L.C.R.; VIEIRA, L.C.R. Ambientes de cultivo, recipientes e substratos na produção de biomassa foliar e radicular em mudas de maracujazeiro amarelo em Aquidauana - MS. Ciência e Agrotecnologia, Lavras, v.34, n.2, p.461-467, 2010 c.

COSTA, E.; LEAL, P.A.M.; MESQUITA, V.A.G.; SASSAQUI, A.R. Efeitos do Organosuper ${ }^{\circledR}$ e do ambiente protegido na formação de mudas de mamoeiro. Engenharia Agrícola, Jaboticabal, v.31, n.1, p.41-55, 2011 a.

COSTA, E.; LEAL, P. A. M.; REGO, N. H.; BENATTI, J. Desenvolvimento inicial de mudas de jatobazeiro do cerrado em Aquidauana-MS. Revista Brasileira de Fruticultura, Jaboticabal, v. 33, n.1, p. 215-226, 2011 b.

COSTA, E.; SANTOS, L.C.R.; CARVALHO, C.; LEAL, P.A.M.; GOMES, V.A. Volumes de substratos comerciais, solo e composto orgânico afetando a formação de mudas de maracujazeiroamarelo em diferentes ambientes de cultivo. Revista Ceres, Viçosa-MG, v.58, n.2, p.216-222, 2011c. 
COSTA, E.; DURANTE, L.G.Y.; NAGEL, P.L.; FERREIRA, C.R.; SANTOS, A. Qualidade de mudas de berinjela submetida a diferentes métodos de produção. Revista Ciência Agronômica, Fortaleza, v.42, n. 4, p.1017-1025, 2011 d.

DIAS, T.J.; PEREIRA, W.E.; CAVACANTE, L.F.; RAPOSO, R.W.C.; FREIRE, J.L.O.

Desenvolvimento e qualidade nutricional de mudas de mangabeiras cultivadas em substratos contendo fibra de coco e adubação fosfatada. Revista Brasileira de Fruticultura, Jaboticabal, v.31, v.2, p.512-523, 2009.

FERREIRA, D.F. SISVAR - Sistema de análise de variância. Versão 5.3. Lavras: UFLA, 2010.

FERREIRA, R.A.; BOTELHO, S.A.; DAVIDE, A.C.; MALAVASI, M. de M. Caracterização morfológica de fruto, semente, plântula e muda de Dipteryx alata Vogel - baru (Leguminosae Papilionoideae). Cerne, Viçosa-MG, v.4, n.1, p.73-87, 1998.

FONSECA, C.E.L.; FIGUEIREDO, S.A.; SILVA, J.A. Influência da profundidade de semeadura e da luminosidade na germinação de sementes de baru (Dipteryx alata VOG). Pesquisa Agropecuária Brasileira, Brasília, v.29, n.4, p.653-659, 1994.

GUISELINI, C.; SENTELHAS, P. C. Uso de malhas de sombreamento em ambientes protegidos. I -Efeito na temperatura e na umidade relativa do ar. Revista Brasileira de Agrometeorologia, Santa Maria, v.12, n.1, p.9-17, 2004.

OLIVEIRA, R.B.; LIMA, J.S.S.; SOUZA, C.A.M.; SILVA, S.A.; MARTINS FILHO, S. Produção de mudas de essências florestais em diferentes substratos e acompanhamento do desenvolvimento em campo. Ciência e Agrotecnologia, Lavras, v.32, n.1, p.122-128, 2008.

PAIVA SOBRINHO, S.; LUZ, P.B.; SILVEIRA, T.L.S.; RAMOS, D.T.; NEVES, L.G.; BARELLI, M.A.A. Substratos na produção de mudas de três espécies arbóreas do cerrado. Revista Brasileira de Ciências Agrárias, Recife, v.5, n.2, p.238-243, 2010.

SANO, S.M.; RIBEIRO, J.F ; BRITO, M.A. de. Baru: biologia e uso. Planaltina: Embrapa Cerrados, 2004. 51 p. (Documentos, 116)

SANO, S.M.; VIVALDI, L.J.; SPEHAR, C.R. Diversidade morfológica de frutos e sementes de baru (Dipteryx alata Vog.). Pesquisa Agropecuária Brasileira, Brasília, v.34, n.4, p.513-518, 1999.

SANTOS, L.C.R.; COSTA, E.; LEAL, P.A.M.; NARDELLI, E.M.V.; SOUZA, G.S.A. Ambientes protegidos e substratos com doses de composto orgânico comercial e solo na formação de mudas de jatobazeiro em Aquidauana-MS. Engenharia Agrícola, Jaboticabal, v.31, n.2, p.249-259, 2011.

SILVA, E.A.; MARUYAMA, W.I.; MENDONÇA, V.; FRANCISCO, M.G.S.; BARDIVIESSO, D.M.; TOSTA, M.S. Composição de substratos e tamanho de recipientes na produção e qualidade das mudas de maracujazeiro 'amarelo'. Ciência Agrotecnologia, Lavras, v.34, n.3, p.588-595, 2010.

SILVA, E.A.; MARUYAMA, W.I.; OLIVEIRA, A.C.; BARDIVIESSO, D.M. Efeito de diferentes substratos na produção de mudas de mangabeira (Hancornia speciosa). Revista Brasileira de Fruticultura, Jaboticabal, v.31, n.3, p.925-929, 2009.

VENTUROLI, F.; FAGG, C.W. FELFILI, J.M. Desenvolvimento inicial de Dipteryx alata Vogel e Myracrodruon urundeuva Allemão em plantio de enriquecimento de uma floresta estacional semidecídua secundária. Bioscience Journal, Uberlândia, v.27, n.3, p.482-493, 2011.

VERA, R.; SOUZA, E.R.B. Baru. Revista Brasileira de Fruticultura, Jaboticabal, v.31, n.1, p.1, 2009. 